DOI https://doi.org/10.30525/978-9934-26-000-1-25

\title{
ВІЗУАЛЬНІ ЗАСОБИ ІНФОРМУВАННЯ В РЕГІОНАЛЬНОМУ НОВИННОМУ ІНТЕРНЕТ-ПРОСТОРІ
}

\author{
Лебідь Н. М. \\ кандидат філологічних наук, \\ доиент кафедри видавничої справи та редагування \\ Романюк Н. В. \\ кандидат філологічних наук, \\ дочент кафедри видавничої справи та редагування \\ Запорізький національний університет \\ м. Запоріжжя, Україна
}

Століття новітніх технологій активізувало візуальну комунікацію практично в усіх сферах життєдіяльності людей, зокрема і в засобах масової інформації (ЗМI), які переходять у мережу інтернет. Вимогою до текстів будь-якої матеріальної форми повідомлень $є$ доступність, легке читання й зорове сприйняття. Така комунікація потребує і відповідних засобів - лінгвістичних, технічних, естетичних тощо, які б співіснували максимально ефективно. Саме ця тематика активно досліджується та обговорюється зараз у наукових колах.

Так, О. Швед вважає, що візуальна комунікація - передача повідомлень, естетично привабливих, інформативних, здатних викликати емоційний відгук у аудиторії. Вона об'єднує мову (текст при читанні «озвучується», проговорюється), опредмечену за допомогою символів (шрифта, малюнок якого також здатний створювати певний рівень сприйняття), графічні елементи (ілюстрації та декоративні елементи найрізноманітнішого плану), колірні рішення (при цьому треба враховувати, що колір символічний як сам по собі, так і в поєднаннях). Успішна комунікація залежить від співвіднесення знань («кодів») журналіста, оформлювача і читача [58, с. 149]I

О. Ситник під візуалізацією контенту розуміє застосування методів подавання інформації у вигляді оптичного зображення (графіки, діаграми, схеми, рисунки, фотографії тощо) з певною комунікативною метою (привернення уваги, інформування, роз'яснення, вплив тощо) [58, с. 149]. Цієї ж думки і А. Рудченко, яка стверджує, що сучасні медіа активно послуговуються саме ілюстративним матеріалом, а також різними технологіями візуалізації інформації [58, с. 149]. С. Небилиця на основі вивчення наукових розвідок за окресленою проблематикою наголошує на тому, що візуалізацію найчастіше застосовують саме в інтернет-ЗМІ, щоб зробити матеріали мультимедійними й цікавими [58, с. 149]. 
Отже, візуальна комунікація в системі 3МІ - це набір інструментів передачі інформації, завдяки яким реципієнт отримує іiі в тому вигляді, в якому йому буде легше іiі сприймати. Під засобами візуальної мови маємо на увазі зображення (фото чи художні), інфографіку, графіки, таблиці, скріншоти, демотиватори, меми, відео тощо, тобто те, що декодуємо і сприймаємо зором, а тому інформацію умовно можна поділити на графічну, що супроводжує текст на сторінці порталу, та ілюстративну, що $\epsilon$ підтвердженням змісту тексту.

Об’єктом дослідження $є$ новинні сайти «061», «Ipnews», «Репортер $\mathrm{UA»,} \mathrm{«Депо»} \mathrm{та} \mathrm{«Громадське.} \mathrm{Запоріжжя»,} \mathrm{вибір} \mathrm{яких} \mathrm{за} \mathrm{пошуком} \mathrm{теми}$ «Новини Запоріжжя». За кількістю переглядів належать до першої п’ятірки.

У ході вивчення засобів візуалізації, які використані в названих онлайнових виданнях, з'ясовано, що в них застосовані такі види мультимедійного контенту, як фото, відео, графіки й таблиці, інфографіка та скріншоти. Не виявлено карикатур, демотиваторів і мемів.

Так, результати аналізу сайтів свідчать, що саме «Репортер UA» за показниками візуалізації інформації є лідером - 95\% усіх журналістських матеріалів містять фотоілюстрації, однак карикатури, фотоколажів за період жовтень-листопад 2020 року не зафіксовано. Тут чотири великих розділи: «Україна», яка включає 10 тегованих підрозділів, «Світ», «Запоріжжя» $\mathrm{i}$ «Віртуальне Запоріжжя», а також бокова панель «Фотоновини». Серед ілюстрацій переважає репортажне фото (75\%), де основна думка та інформація візуалізовані, а текст лише коментує зображення. Не менш поширеною є й об'єктна зйомка (45\%). Зауважимо, що журналісти використовують і серії фото - по 2-3 на матеріал. А ось новинарна фотографія (23\%) доповнює текстове повідомлення. Більшість фотографій редакція видання бере з інтернету і подає їх із дотриманням усіх вимог. Графіки та таблиці візуалізують інформацію в рубриці «Економіка» $(15 \%$ з усіх публікацій, що стосуються цін на продукти, комунальні послуги, а також зарплат і пенсій), оскільки тут тексти містять багато цифрових даних і для полегшення сприйняття їх унаочнюють.

Сайт «Громадське. Запоріжжя» має розділи: «LIVE», «Спецпроєкти», «Новини», «Статті», «Думки», «Програми», окремо виділена рубрика «Відео». Матеріали тут у своїй більшості візуалізовані ілюстраціями (86\%), а також шрифтовими та кольоровим виділеннями. Яскравою є рубрика «Спецпроєкти», де розміщені багатосерійні матеріали не лише із відеосюжетами, а й подані лонгріди, що поєднують низку візуальних елементів (шрифти, лінії, повітря тощо). Новинарна світлина виявлена в окремих випадках (12\%). Для спрощення читання текстів застосовують повітря і помаранчеві лінійки, які відділяють публікації. У рубриці «Відео» кожне відео супроводжується коротеньким текстом, який $є$ «підводкою» до нього, анонсом його основної теми. 
Що стосується сайту «Депо. Запоріжжя», то тут переважає новинарні й об'єктні фото (95\%), які супроводжують замітки, а репортажна зйомка використовується при висвітленні масштабних заходів у місті: День міста, Покровський ярмарок, фестиваль їди та фестиваль консервації в Дубовому гаю (рубрики «Новини», «Життя»). Як бачимо, це поодинокі випадки візуалізації інформації, коли метою публікації $\epsilon$ документальна передача атмосфери заходів та створення ефекту присутності читача на цих подіях. Ні таблиць, ні графіків, ні інфорграфіки не виявлено, навіть у рубриці «Гроші», де подають новини з економіки країни. Однак активно використовують скріншоти із соціальних мереж i в окремих матеріалах - відео (8\%).

Ha «Ipnews», на відміну від проаналізованих сайтів, нема окремих фотоновин чи фоторубрик, тут не вживають і поняття «фоторепортаж» у назві рубрики чи підрубрики («Головне», «Медіа», «Популярне»). Про наявність відео чи фото в публікації вказують у заголовку (наприклад, «Не почув сигналу: у Запоріжжі потяг збив чоловіка» (Фото), «У Запоріжжі жінка полювала на голубів (Відео)»). Відео і фото беруть або із соціальних мереж, про що повідомляють у тексті («автор розмістив відео у фейсбуці») чи інших ЗМІ («інформацію надрукував «Забор»). Портретні фото представників міської та державної влади йдуть без підписів. Переважає новинарна й об'єктна зйомка (80\%), де на кожній світлині у правому кутку проставлений фірмовий знак. Інфографікою не послуговуються, і це передбачувано, оскільки мета сайту - оперативно подавати новини, інформацію.

Дані дослідження засвідчили найнижчий показник сприйняття інформації саме на сайті «061», оскільки новини міста подані не списком, а віконцями $з$ фотографіями, на яких ще й розміщені заголовки. Усе це створює ефект безладу та нагромадження різних засобів візуалізації. Однак це єдиний діючий довідник міста, де $є$ контакти всіх закладів міста, погода, реклама різних послуг, оголошення, вакансії та багато іншого. Основні рубрики - «Новини», «Довідка», «Дозвілля», «Афіша», $\epsilon$ підрубрика «Фотозвіти». Переважають новинарні світлини, велика кількість фотоколажів. Новинні тексти супроводжуються інфографікою, фото документів, скріншотами зі сторінок інших сайтів. Однак тут відео - це поодинокий факт (11\%). Таблиці, графіки та діаграми не виявлені.

Вивчивши графічну модель п'яти новинних порталів Запоріжжя, прийшли до висновку, що чотири з них (окрім «061») активно використовують як засіб візуалізації інформації відеоматеріали. Так, «Депо. Запоріжжя», «Репортер UA», «Ipnews» розміщують запозичене відео із соціальних мереж, офіційних сторінок державних і громадських організацій та з інших ЗМІ. «Громадське. Запоріжжя» та портал «061» у власних проєктах створюють власний контент, завдяки чому і $€$ популярними серед молоді. 
Отже, впровадження нових тенденцій, при яких традиційна структура ЗМІ змінюється та трансформується, поява нових форм обробки та передачі інформації, поєднання декількох каналів на одній платформі - усе це $\epsilon$ i в регіональних ЗМІ Запоріжжя. Що стосується новітніх засобів візуалізації, то також можна відзначити роботу лише декількох редакцій. Для «Громадського. Запоріжжя» характерні лонгріди та відео, але не як самостійний ролик, а як відзнятий коментар. Також на «061» багато інфографіки та лонгрідів, де чітко виділені ключові цитати, розставлені фразові наголоси. До того ж на «061» багато так званих фотоколажів, які краще роз'яснюють читачеві великий обсяг текстів. Не $\epsilon$ популярним засобом візуальної комунікації на сторінках регіональних новинних онлайнових ЗМІ демотиватори, меми й карикатури. Це, очевидно, пов'язано із специфікою видань - оперативно повідомити факт, новину.

Аналіз рейтингових у запорізькому регіоні інтернет-видань дозволив виділити найпоширеніші засоби візуалізації інформації, які використовують на їхніх сторінках. Однак подальшого дослідження потребують якість і відповідність таких елементів змісту основного тексту.

\section{Література:}

1. Небилиця С. І. Засоби візуалізації інформації в онлайнових виданнях. Актуальні проблеми природничих та гуманітарних наук у дослідженнях молодих учених «Родзинка - 2018»: матеріали XX Всеукраїнської наукової конференції молодих учених. 19-20 квітня 2018. Черкаси, 2018. URL: http://eprints.cdu.edu.ua/1498/1/rodzinka_2018_2.pdf.

2. Рудченко А.С. Візуалізація як тренд у сучасних конвергентних медіа. Збірник наукових праць професорсько-викладацького складу ДонНУ імені Василя Стуса за 2015-2016 pp. URL: http://jpvs.donnu.edu.ua/ article/viewFile/3688/3721.

3. Ситник О. Візуальна комунікація в системі композиційно-графічного моделювання інформаційних порталів. Педагогічні інноващіï: iдеї, реалї, перспективи. 2014. Вип. 2. С. 87-93. URL: http://nbuv.gov.ua/ UJRN/ped_in_2014_2_16

4. Швед О. В. Інфографіка як засіб візуальної комунікації в сучасній журналістиці. Гуманітарна освіта в технічних вищих навчальних закладах: зб. наук. праць. Київ : Університет «Україна», 2014. Вип. 30. C. $305-313$. 